\title{
Fiscal Theory of the Price Level
}

\author{
Marco Bassetto* \\ Federal Reserve Bank of Chicago, University of Minnesota, and NBER
}

\begin{abstract}
The fiscal theory of the price level (FTPL) describes fiscal and monetary policy rules such that the price level is determined by government debt and fiscal policy alone, with monetary policy playing at best an indirect role. This theory clashes with the monetarist view that states that money supply is the primary determinant of the price level and inflation. Furthermore, many authors have argued that the fiscal rules upon which the FTPL relies are misspecified. We review the sources of disagreement, and highlight aspects upon which some consensus has emerged.
\end{abstract}

The fiscal theory of the price level (FTPL) describes policy rules such that the price level is determined by government debt and the present and future tax and spending plans, with no direct reference to monetary policy.

In understanding the FTPL and tracing its roots, we start from two simple relations: the velocity equation and the government budget constraint.

The velocity equation defines the velocity of money in period $t\left(V_{t}\right)$ as the ratio of nominal output (the price level $P_{t}$ times real output $\left.Y_{t}\right)$ to nominal money balances $\left(M_{t}\right)$ :

$$
V_{t}=\frac{P_{t} Y_{t}}{M_{t}}, \quad t=0,1, \ldots
$$

*The New Palgrave Dictionary of Economics, forthcoming, Palgrave Macmillan, reproduced with permission of Palgrave Macmillan. This article is taken from the author's original manuscript and has not been reviewed or edited. 
Differences across monetary models arise in the way these four economic variables are determined, and in the specification of which (if any) of these variables is to be treated as exogenous vs. endogenous. Prior to the introduction of the FTPL, equation (1) was viewed as the primary determinant of the price level. As an example, the quantity theory of money states that $V_{t}$ is fixed and exogenous. In this case, the price level is proportional to the money supply. High prices arise because too much money is chasing too few goods, which is the heart of the monetarist doctrine. In a more sophisticated theory, velocity is itself affected by other macroeconomic variables, chief among them the nominal interest rate. Furthermore, in general, the price level needs to be determined jointly with $M_{t}, Y_{t}$, and $V_{t}$ by computing the entire equilibrium path of the economy. The FTPL traces its roots to an incompleteness in the monetarist view of the price level: often, the equilibrium price level fails to be uniquely determined, i.e., there are many paths of $P_{t}$ that satisfy (1) as well as all the other equilibrium requirements (see discussion in Kocherlakota and Phelan 1999). This is especially true when monetary policy prescribes an exogenous interest rate; Sargent and Wallace (1975) show that the initial price level is then indeterminate, and subsequent inflation is subject to 'sunspots,' uncertainty driven by self-fulfilling expectations. In the simplest case, an interest rate peg determines the level of velocity $\left(V_{t}\right)$, and real output and interest rates are independent of money and prices; equation (1) then pins down real money balances $\left(M_{t} / P_{t}\right)$, but it does not specify whether those balances will be attained by high or low nominal money supply and prices.

The FTPL (Woodford 1994, Sims 1994) determines prices from a different equation:

$$
\frac{B_{t}}{P_{t}}=\text { Present value of primary fiscal surpluses as of time } t, \quad t=0,1, \ldots,
$$

where $B_{t}$ is the nominal value of government liabilities (debt and money) at the beginning of period $t$. Equation (2) is the government budget constraint, in its present value form: the lefthand side represents real government liabilities, matched by assets on the right-hand side. In its simplest form, the FTPL assumes that the government commits to a fixed and exogenous present value of primary fiscal surpluses; this is a special case of what Leeper (1991) defines an 'active' fiscal policy and Woodford (1995) a 'Non-Ricardian' fiscal regime. Given an initial condition for debt, $B_{0}$, a unique price level is consistent with (2): the FTPL successfully selects 
a unique price level at time 0 , even in the case of an interest rate peg, for which the monetarist view offered no prediction. The power of the FTPL is not limited to period 0; the possibility of sunspot equilibria is ruled out in all subsequent periods, since again a unique level of prices is consistent with a given present value of surpluses and the nominal debt inherited from the past. Nonetheless, monetary policy does have an effect on inflation after period 0: the evolution of nominal liabilities $B_{t}$ depends on the nominal interest rate, which is affected by monetary policy.

Since its inception, the FTPL has been extremely controversial. I will focus here on two main areas of concern.

1. The price level is defined as the inverse of the value of money: how much money it takes to buy a given basket of goods. By contrast, the FTPL is about the inverse of the value of government debt. This is explained particularly clearly in Cochrane (2005). As Buiter (2002) points out, there is no reason in general for the value of debt and the value of money to coincide. To the extent that households anticipate a government default, they may trade government debt at a discount, without necessarily affecting the value of money. This criticism is particularly serious when the central bank adopts a monetary policy that rules out monetization of government debt. As an example, consider the case in which the central bank adopts a constant money supply rule and does not engage in open market operations. In this case, there is no link between government debt and money, and no reason why a maturing T-Bill with a face value of $\$ 1,000$ should trade at par with ten $\$ 100$ notes issued by the central bank. Maturing debt and money will only trade at par if fiscal policy is run in such a way that the government will have the appropriate amounts of money to repay its debt, independently of the price level: this requires real tax revenues to adjust to prices, violating the central assumption of the FTPL.

The same criticism does not apply when the monetary policy of the central bank allows unlimited monetization of debt, as in the case of an interest rate peg. In this case, the central bank commits to exchange arbitrary amounts of money and one-period government debt at a fixed price. This commitment is not inconsistent with a second commitment, to redeem all maturing government debt at par, offering money in exchange. Since the 
central bank has unlimited ability to produce money, a government default on nominal debt is now ruled out. In this case, the FTPL is simply a version of a commodity money standard; money, as well as other government liabilities, is backed by the present value of future government surpluses, just as the value of Microsoft shares is backed by the present value of Microsoft profits (this is the main example in Cochrane 2005).

While the original treatment of the FTPL was ambiguous (in particular, Woodford (1995) considers the case of the FTPL under a money supply rule), it is now widely agreed that the FTPL requires an implicit or explicit institutional commitment to prevent a government default (or excess repayments by the government) through an appropriate (de)monetization of debt. In this form, the FTPL bears some similarities with the "unpleasant monetarist arithmetic' of Sargent and Wallace (1981). Under the monetarist arithmetic, a fiscal deficit imbalance will trigger inflation, because seigniorage revenues are necessary to prevent the government from defaulting. Even though monetization of government debt plays a central role in both theories, there are important differences. According to the unpleasant monetarist arithmetic, seigniorage revenues (which are part of the present value of surpluses in equation (2)) will have to respond to changes in $P_{t}$ to ensure that the government budget constraint holds; hence, equilibrium occurs through adjustments in the right-hand side of (2). In the FTPL, seigniorage revenues on the monetary base play at best a minor role. Under the FTPL, it is the price level that responds to shocks to spending and taxes; its fluctuations cause the real value of debt (the left-hand side of (2)) to appreciate or depreciate to reach an equilibrium.

2. The FTPL is based on the assumption that equation (2) holds only at an equilibrium. The critics of the FTPL view instead (2) as a constraint that forces the government to match the real value of debt with an appropriate present value of primary surpluses, for all conceivable levels of prices. To better understand the issue, it is useful to note that (2) looks identical to the intertemporal budget constraint of any household in the economy: it is sufficient to relabel $B_{t}$ as the nominal liabilities of the household, and the right-hand side as the present value of its non-asset income, net of consumption. In the case of a household, 
there is universal agreement that (2) should be viewed as a constraint: given any value of $P_{t}$, the household must choose a consumption/income plan that satisfies (2). The critics of the FTPL argue that the government should be no different from any other agent. Unlike the previous criticism, the heated debate that has emerged on this point has not resulted in widespread agreement. As Bassetto (2005) pointed out, the disagreement stems from a fundamental weakness in the tools that have been used to study this problem. Both critics and supporters of the FTPL adopt the dynamic competitive equilibrium framework. This framework is designed for environments populated by many small players; in the presence of a large and potentially strategic player, such as the government, it offers little guidance in distinguishing between equilibrium conditions, and constraints that the large player(s) faces under any circumstances, even away from an equilibrium. While there are many applications for which this ambiguity is not important, a proper account of the distinction is essential to study the uniqueness or multiplicity of equilibria, which is the object of interest in the case of the FTPL.

To overcome this difficulty, Bassetto (2002) explicitly describes the economy as a game, where the actions available to all households and the government at any point in time are clearly spelled out. Bassetto shows that the basic version of the FTPL, with an unconditional commitment to a sequence of primary surpluses, is not a valid government strategy in a well-specified game, at least if the sequence includes a primary deficit at any point in time. Intuitively, a primary deficit is only possible if the government is able to raise revenues through borrowing. Since lending is voluntary (as opposed to payment of taxes), any plausible game includes the possibility that private agents will not lend; if this circumstance arises, the government is forced to a fiscal adjustment. Bassetto then proves that there exist other government strategies that lead to a unique equilibrium price level that is determined from taxes and spending alone. These strategies paint a very different picture of the conditions under which a FTPL arises: whereas the traditional view relies on the government setting taxes and spending exogenously, with no regard for the evolution of debt, the strategies described by Bassetto require the government to strongly react to 
incipient 'debt crises' by accumulating larger surpluses in present value.

A small empirical literature (e.g. Canzoneri, Cumby, and Diba 2001, Cochrane 2001) has looked into the usefulness of (2) in accounting for the evolution of prices. The results are not very favorable; in particular, when a government runs an unexpected deficit, the real market price of its debt increases, suggesting that households expect that the government will make up for the shortfall through increased surpluses in the future. If future surpluses were exogenous and fixed, (2) would suggest that an unexpected deficit should have its primary effect through inflation, by depressing the real market value of debt. While these observations cannot refute the central claim of the FTPL, that (2) is only an equilibrium condition, they call into question the usefulness of the FTPL to explain actual inflationary episodes.

Recent research into monetary policy has looked for interest rate rules that ensure price level determinacy independently of the fiscal policy of the government; this has weakened interest in the FTPL. Though no issue as controversial as the FTPL has emerged since, this recent analysis is still open to ambiguous distinctions between policy rules, that should capture government behavior in all possible scenarios, and equilibrium relations across the endogenous variables of an economic system. A more complete analysis awaits the development of new tools that are as simple and powerful as dynamic competitive equilibrium, and yet able to appropriately capture the special role of the government.

Marco Bassetto

\section{References}

Bassetto, M. (2002). A game-theoretic view of the fiscal theory of the price level. Econometrica $70(6), 2167-2195$.

Bassetto, M. (2005). Equilibrium and government commitment. Journal of Economic Theory $124(1), 79-105$.

Buiter, W. H. (2002). The fiscal theory of the price level: A critique. Economic Journal 112(481), 459-480. 
Canzoneri, M. B., R. E. Cumby, and B. T. Diba (2001). Is the price level determined by the needs of fiscal solvency? American Economic Review 91(5), 1221-1238.

Cochrane, J. H. (2001). Long term debt and optimal policy in the fiscal theory of the price level. Econometrica 69(1), 69-116.

Cochrane, J. H. (2005). Money as stock. Journal of Monetary Economics 52(3), 501-528.

Kocherlakota, N. R. and C. Phelan (1999). Explaining the fiscal theory of the price level. Federal Reserve Bank of Minneapolis Quarterly Review 23(4), 14-23.

Leeper, E. (1991). Equilibria under 'active' and 'passive' monetary policies. Journal of Monetary Economics 27(1), 129-147.

Sargent, T. J. and N. Wallace (1975). 'Rational' expectations, the optimal monetary instrument, and the optimal money supply rule. Journal of Political Economy 83(2), 241-254.

Sargent, T. J. and N. Wallace (1981). Some unpleasant monetarist arithmetic. Federal Reserve Bank of Minneapolis Quarterly Review 5(3), 1-17.

Sims, C. A. (1994). A simple model for study of the determination of the price level and the interaction of monetary and fiscal policy. Economic Theory 4(3), 381-399.

Woodford, M. (1994). Monetary policy and price level determinacy in a cash-in-advance economy. Economic Theory 4(3), 345-380.

Woodford, M. (1995). Price level determinacy without control of a monetary aggregate. Carnegie-Rochester Conference Series on Public Policy 43, 1-46. 